\title{
PROŠIRENOST DOJENJA I C̆IMBENICI KOJI UVJETUJU ODUSTAJANJE OD DOJENJA NA PODRUČJU MOSTARA
}

\author{
Ivana Palac ${ }^{1}$, Darinka Šumanović-Glamuzina², Iva Mikulić ${ }^{1}$, Gordan Galić3 \\ ${ }^{1}$ Klinika za kirurgiju, Sveučilišna Klinička bolnica Mostar \\ ${ }^{2}$ Klinika za pedijatriju, Sveučilišna Klinička bolnica Mostar \\ ${ }^{3}$ Fakultet zdravstvenih studija, Sveučilište u Mostaru
}

\section{SAŽETAK}

UVOD: Prehrana majčinim mlijekom je prirodan i najbolji način prehrane u dojenačkoj dobi. Modernizacija ljudskog društva uza sve prednosti donosi i neke nedostatke, posebice udaljavanje od prirode i nekih prirodnih procesa, među koje pripada i prehrana majčinim mlijekom. Novija znanstvena istraživanja i opsežne epidemiološke studije dokazale su prednosti prirodne prehrane na zdravlje djece. Dojenje povoljno djeluje na dijete, majku, obitelj i društvo u cjelini, stoga su zaštita, promicanje i potpora dojenju javno-zdravstveni prioritet svih zemalja.

CILJ: Usporediti i odrediti sociodemografske i ostale specifične razlike između dojilja i nedojilja.

ISPITANICI I POSTUPCI: Istraživanje je provedeno u Domu zdravlja Mostar, na Odjelu za zdravstvenu zaštitu dojenčadi i male djece u siječnju 2013. godine. Anketnim upitnikom uz prethodno potpisani informirani pristanak, ispitano je ukupno 300 slučajno odabranih, ali ciljano podijeljenih u dvije približno jednake skupine dojilja (145) i nedojilja (155).

REZULTATI: Usporedbe između skupine dojilja i nedojilja potvrđuju statistički značajnu razliku u odnosu na obrazovanje, materijalni status, utjecaj pušenja, prethodno dojenje, vrstu porođaja i utjecaju dojenosti majke kao djeteta. Također značajnim se pokazao utjecaj stava o uspjehu dojenja prije samog početka dojenja. Za najučestaliji izvor podrške u dojenju majke koje doje svoju djecu navode da su bile same sebi, a potom su tu podršku našle u ocu djeteta ili majci. Najučestalije naveden razlog prestanka dojenja bila je nedovoljna količina majčinog mlijeka, a potom umor i stres.

ZAKLJUČAK: Rezultati ukazuju na potrebu edukacije o dojenju, jer dobra priprema i edukacija prije poroda i dobra podrška nakon poroda uvelike bi pridonijela povećanju prevalencije dojenja.

KLJUČNE RIJEČI: dojenje, čimbenici rizika, dojenče.

Osoba za razmjenu informacija:

Mr.sc. Ivana Palac, diplomirana medicinska sestra.

e-mail: ivanapalac1985@gmail.com

\section{UVOD}

Tisućama godina kroz povijesti majčino je mlijeko bilo jedina mogućnost prehranjivanja novorođenog djeteta (1). Dojenje je bilo oduvijek važno, međutim u jednom razdoblju ljudske povijesti u 20. stoljeću, obilježenom snažnom industrijalizacijom, primijetilo se da dojenče jednako dobro napreduje na umjetnoj prehrani. Budući da tada još nije bilo tako sofisticiranih proizvoda pristupilo se adaptiranju kravljeg mlijeka. Na neko vrijeme se odustalo od dojenja, odnosno vrlo mali broj djece je prirodno hranjen. To je bio jedan veliki prirodni eksperiment koji i nije baš dobro završio. Ispitivanja su pokazala da majčino mlijeko ima neka svojstva koja prijašnjim analizama nisu bila poznata. Otkriveno je da majčino mlijeko sadrži primjerenu količinu bjelančevina upravo potrebnu za rast djeteta te mlade dobi, da sadrži minerale koji ne opterećuju njegovu mijenu tvari, te neke bitne tvari kao što su nezasićene masne 
kiseline u onoj količini koja je djetetu neophodna, prije svega za razvoj središnjeg živčanog sustava. Pored toga otkriveno je da majčino mlijeko sadrži veću količinu šećera od kravljeg mlijeka (2). Sve to djeluje previše sterilno i umjetno, a stvarne posljedice na ljudsko biće koje prolazi kroz tu preobrazbu još nisu do kraja sagledane (3). Kad su uočene sve te razlike počela se vraćati praksa da se djeca prirodno hrane na prsima majke. Kako se u svemu nastojimo vratiti prirodi, tako je i u ovome, možda najbitnijem $\mathrm{u}$ prirodi, a to je prirodna prehrana (4). Tako je u razvijenim zemljama ponovo prisutan trend povećanja broja dojene djece. Teži se humanom rađanju, kojemu mogu prisustvovati i očevi, povećava se broj „Bolnica prijatelja djece“, u kojima je moguć cjelodnevni smještaj djeteta uz majku (rooming in) i dojenje odmah nakon poroda (3). Dojenje je prirodno pravo djeteta i slobodan izbor svake majke, ne nešto sramotno ili prosto, već nešto istinski lijepo i drevno (5). Program unapređenja dojenja predstavlja važnu strategiju Svjetske zdravstvene organizacije (SZO), s ciljem što većeg preživljavanja dojenčadi i male djece, osobito u siromašnijim zemljama, s nedovoljnom zdravstvenom prosvijećenošću (6).

Svjetsku organiziranu akciju povratka dojenju, zaštite, poticanja i podupiranja dojenju pokrenule su SZO i UNICEF, (engl. United Nations Children's Found), te su donijeli preporuke za promicanje dojenja u rodilištima i novorođenačkim odjelima u obli$\mathrm{ku}$ „Deset koraka do uspješnog dojenja“ $(7,8)$. Prema Konvenciji o pravima djeteta svako dijete ima pravo na optimalnu prehranu, rast i razvoj. Spoznaja o potrebi programiranih djelatnosti za promicanje dojenja rezultirala je pokretanjem globalnih inicijativa i preporuka od strane SZO-a i UNICEF-a pod nazivom Deklaracija Innocenti o zaštiti, poticanju i podupiranju dojenja 2005. god. i Globalnom strategijom o prehrani dojenčeta i male djece 2003. god. (9-11).

Bosna i Hercegovina potpisnica je „Globalne inicijative i Konvencije o pravima djeteta “ još od 1993. godine (6). Razlozi za prestanak dojenja $u$ većini slučajeva je nedostatak mlijeka što upućuje da majke nisu dovoljno upućene u tehniku dojenja (12). Agresivna promocija proizvođača zamjenskih pripravaka bila je praksa tijekom posljednjih desetljeća. Nakon ratnih zbivanja i degradacije važnosti dojenja, u proteklom desetljeću počela je aktivnija promocija dojenja koja je u stalnom usponu sa izrazito efektivnim učincima i osviještenosti društva u cjelini (13). Da bi dojenje bilo efikasno, i dojenče i majka moraju znati svoju ulogu i naučiti kako se doji jer je dojenje vještina koja se uči (14). Prijašnja istraživanja na području $\mathrm{FBiH}$, kao i studentska istraživanja na području Hercegovine kao glavni razlog prestanka dojenja navode nedostatak mlijeka (16). Taj je problem međutim samo iznimno stvaran. Agalaktija postoji, ali je izvanredno rijetka pojava. U zdravih žena svaka dojka, bez obzira na veličinu, može stvoriti dovoljno mlijeka, ako je njegova proizvodnja stimulirana na prikladan način. Glad djeteta, njegov apetit i sisanje najbolji su poticaj za stvaranje mlijeka. Ako dijete dobro i dosta često siše, u prvih 10 do 14 dana dojenja, ustalit će se proizvodnja oko $1 / 2$ litre mlijeka, što će zadovoljiti potrebe djeteta. Ako je dijete gladnije i još više siše, proizvodnja mlijeka će dalje rasti (7).

Cilj rada je istražiti kakva je praksa prirodne prehrane dojenčadi te usporediti i odrediti sociodemografske i ostale specifične različke između dojilja i nedojilja.

\section{ISPITANICI I POSTUPCI}

Istraživanje je provedeno u Domu zdravlja Mostar, Odjel za zdravstvenu zaštitu dojenčadi i male djece, Općina Mostar. Obuhvaćene su majke koje su dolazile u Odjel za zdravstvenu zaštitu dojenčadi i male djece sa djecom starosti do 12 mjeseci, u razdoblju od mjesec dana. Ispitanice su dobile anketni upitnik osobino te se mogla pratiti točnost popunjavanja pitanja, i/ili razjasniti ukoliko je neko od pitanja bilo nejasno. Nije bilo nepravilno popunjenih upitnika.

Provedena je presječna studija pomoću specifično konstruiranog, šifriranog anketnog upitnika na 300 ispitanica. Ispitanice su podijeljene u dvije skupine: 1. majke koje doje svoje dijete-dojilje i 2. majke koje ne doje-nedojilje. U skupini majki dojilja bilo je 145 ispitanica, a u skupini majki koje ne doje 155 ispitanica. Sudjelovanje u istraživanju bilo je dragovoljno 
i anonimno, pokriveno potpisanim informiranim pristankom sudionica u istraživanju.

Upitnik se sastojao od tri dijela. Prvi dio ispunile su sve ispitanice, drugi dio ispunjavale su majke koje doje, a treći dio ispunjavale su majke koje ne doje svoju djecu. Prvi dio je općeniti dio upitnika koji se sastojao od sociodemografskih pitanja: dob majke, stručna sprema, zaposlenost, materijalni status, mjesto stanovanja, navika pušenja, redoslijed djeteta, prethodno iskustvo dojenja, vrsta porođaja. Također, u prvom djelu upitnika saznalo se jesu li ispitanice bile dojene kao djeca, kakav im je stav o dojenju bio prije porođaja, te od čije strane su educirane o dojenju i jesu li pohađale tečaj pripreme za porođaj. Svi dobiveni podatci su komparirani između ispitivanih skupina. Drugim djelom upitnika dobiveni su podatci o dobi dojene dojenčadi, vrsti dojenja, te o pružanju podrške u dojenju.

Treći dio upitnika otkriva razloge prestanka dojenja, osjećaj u vezi istog, te mogući utjecaj drugih na prestanak dojenja. Ispitanice su trebale zaokružiti svoj odgovor, a ukoliko odgovor nije bio jedan od navedenih imale su opciju upisati vlastiti komentar.

\section{Statistička obrada}

Za analizu nominalnih i ordinalnih varijabli korišten je hi kvadrat test. Pri manjku očekivane frekvence, u kategorijskim varijablama s više podskupina korišten je modul dodatnih egzaktnih testova. Za testiranje simetričnosti raspodjele kontinuiranih podataka korišten je Kolmogorov-Smirnovljev test. Za prikaz kontinuiranih varijabli koristio se medijan i interkvartilni raspon zbog raspodjele koja je značajno odstupala od normalne, zbog čega se za njihovu usporedbu koristio Mann-Whitney $\mathrm{U}$ test. Mogućnost pogrješke prihvatila se pri $\alpha<0,05$ te su razlike između skupina bile prihvaćene kao statistički značajne za $\mathrm{p}<0,05$.

Za statističku analizu dobivenih podataka rabljen je programski sustav SPSS for Windows (inačica 17.0, SPSS Inc, Chicago, Illinois, SAD) i Microsoft Excell (inačica 11. Microsoft Corporation, Redmond, WA, SAD).

\section{REZULTATI}

\section{Sociodemografske razlike između skupine dojilja i nedojilja}

Nije postojala značajna razlika u dobnoj strukturi između ispitanica koje su dojile i onih koji nisu dojile $(\mathrm{p}=0,220)$. Dok je u dojilja bio značajno veći broj ispitanica s VŠS, u nedojilja su značajno više bile učestale osobe sa srednjom stručnom spermom (hi kvadrat test $=6,992 ; \mathrm{df}=2 ; \mathrm{p}=0,030$ ). $\mathrm{U}$ dojilja je materijalni status ocijenjen dobrim u značajno većem broju u odnosu na nedojilje (hi kvadrat test $=10,686 ; \mathrm{df}=3 ; \mathrm{p}=0,014$ ). Obje istraživane skupine bile su u približno jednakom omjeru zaposlene (hi kvadrat test $=2,494$; $\mathrm{df}=1$; $\mathrm{p}=0,114)$. Mjesto stanovanja nije se značajno razlikovalo između ove dvije promatrane skupine (hi kvadrat test $=1,591 ; \mathrm{df}=1 ; \mathrm{p}=0,207)$. Nedojilje su u značajno većoj mjeri imale naviku pušenja u odnosu na dojilje (hi kvadrat test $=26,309 ; \mathrm{df}=2 ; \mathrm{p}=0,001)$ (Tablica 1 ).

Tablica 1. Sociodemografske i ostale značajke usporedene izmedu skupina

\begin{tabular}{|c|c|c|c|c|}
\hline \multirow{2}{*}{ Varijable } & \multicolumn{2}{|c|}{ N \% ispitanica po skupini } & \multirow{2}{*}{$\begin{array}{l}\text { Hi kvadrat } \\
\text { test }\end{array}$} & \multirow{2}{*}{$p$} \\
\hline & Dojilje & Nedojilje & & \\
\hline Dob & & & & 0,220 \\
\hline$<18 \operatorname{god}$ & 0 & $2(1,3)$ & & \\
\hline $18-25 \mathrm{god}$ & $25(17,2)$ & $38(24,5)$ & & \\
\hline $25-35$ & $94(64,8)$ & $89(57,4)$ & & \\
\hline$>35$ & $26(17,9)$ & $26(16,8)$ & & \\
\hline Obrazovanje & & & 6,992 & 0,030 \\
\hline 05 & $3(2,1)$ & $11(7,1)$ & & \\
\hline SSS & $72(49,7)$ & $87(56,1)$ & & \\
\hline VŠs i ostalo & $70(48,3)$ & $57(36,8)$ & & \\
\hline Zaposlenost & & & 2,494 & 0,114 \\
\hline $\mathrm{Da}$ & $71(49,0)$ & $90(58,1)$ & & \\
\hline $\mathrm{Ne}$ & $74(51,0)$ & $65(41,9)$ & & \\
\hline Materijalni status & & & 10,686 & 0,014 \\
\hline Vrlo loš & $8(5,5)$ & $7(4,5)$ & & \\
\hline Loš & $18(12,4)$ & $38(24,5)$ & & \\
\hline Dobar & $113(77,9)$ & $97(62,6)$ & & \\
\hline Jako dobar & $6(4,1)$ & $13(8,4)$ & & \\
\hline Mjesto stanovanja & & & 1,591 & 0,207 \\
\hline Selo & $50(34,5)$ & $43(27,7)$ & & \\
\hline Grad & $95(65,5)$ & $112(72,3)$ & & \\
\hline Navika pušenja & & & 26,309 & $<0,001$ \\
\hline $\mathrm{Da}$ & $27(18,6)$ & $67(43,2)$ & & \\
\hline $\mathrm{Ne}$ & $99(68,3)$ & $62(40,0)$ & & \\
\hline Povremeno & $19(13,1)$ & $26(16,8)$ & & \\
\hline
\end{tabular}


Palac I, Šumanović-Glamuzina D, Mikulić I, Galić G. Proširenost dojenja i čimbenici koji uvjetuju odustajanje od dojenja na području Mostara. Zdravstveni glasnik. 2016;2: 35-46.

Redoslijed djeteta nije se značajno razlikovao između dojilja i nedojilja (hi kvadrat test $=2,229$; $\mathrm{df}=3$; $\mathrm{p}=0,526)$. Dojilje su u značajnoj mjeri učestalije imale prethodno dojenje u odnosu na skupinu nedojilja $\mathrm{u}$ ovom istraživanju (hi kvadrat test $=31,716 ; \mathrm{df}=1$; $\mathrm{p}<0,001)$. Isto tako, dojilje su u značajno većem broju bile dojene kao djeca u odnosu na nedojilje (hi kvadrat test $=42,645 ; \mathrm{df}=1 ; \mathrm{p}<0,001)$. Dojilje su najučestalije imale kao vrstu porođaja prirodan porođaj $\mathrm{u}$ odnosu na nedojilje (hi kvadrat test $=6,248 ; \mathrm{df}=1$; $\mathrm{p}=0,012)$ (Tablica 2).

Tablica 2. Usporedba pariteta, vrste porođaja i prethodnog dojenja izmedu skupina

\begin{tabular}{|l|l|l|l|l|}
\hline \multirow{2}{*}{ Varijable } & \multicolumn{2}{|l|}{ N \% ispitanica po skupini } & Hi kvadrant & \multirow{2}{*}{ test } \\
\cline { 2 - 3 } & Dojilje & Nedojilje & \\
\hline Redoslijed djeteta & & & 2,229 & 0,526 \\
\hline Prvo & $52(35,9)$ & $55(35,5)$ & & \\
\hline Drugo & $55(37,9)$ & $63(40,6)$ & & \\
\hline Treće & $28(19,3)$ & $32(20,6)$ & & \\
\hline Četvrto i više & $10(6,9)$ & $5(3,2)$ & & \\
\hline Prethodno dojenje & & & 31,716 & $<0,001$ \\
\hline Da & $89(61,4)$ & $45(29,0)$ & & \\
\hline Ne & $56(38,6)$ & $110(71,0)$ & & \\
\hline Vrsta poroda & & & 6,248 & 0,012 \\
\hline $\begin{array}{l}\text { Prirodan } \\
\text { porodaj }\end{array}$ & $119(82,1)$ & $108(69,7)$ & & \\
\hline Carski rez & $26(17,9)$ & $47(30,3)$ & & \\
\hline Dojeni kao dijete & & & 42,645 & $<0,001$ \\
\hline Da & $127(87,6)$ & $82(52,9)$ & & \\
\hline Ne & $18(12,4)$ & $73(47,1)$ & & \\
\hline
\end{tabular}

Dok su u dojilja najučestaliji izvor informacija o dojenju bile majke, medicinske sestre i mediji, u nedojilja mnogo učestalije nije bilo izvora informacija $\mathrm{u}$ odnosu na dojilje, a od prisutnih izvora informacija najučestalije su to bile također majke $(\mathrm{p}<0,001)$.
Tablica 3. Usporedba izvora informacija izmedu skupina

\begin{tabular}{|l|l|l|}
\hline \multirow{2}{*}{ Izvor informacija } & \multicolumn{2}{|l|}{ Broj \% pozitivnih odgovora } \\
\cline { 2 - 3 } & Dojilje & Nedojilje \\
\hline Majka (majčina majka) & $70(48,3)$ & $58(37,4)$ \\
\hline Otac (suprug) & $13(9,0)$ & $2(1,3)$ \\
\hline Prijatelji & $28(19,3)$ & $7(4,5)$ \\
\hline Medicinske sestre & $44(30,3)$ & $34(21,9)$ \\
\hline Liječnici & $42(29,0)$ & $48(31,0)$ \\
\hline Mediji & $43(29,7)$ & $28(18,1)$ \\
\hline Nitko & $12(8,3)$ & $43(27,7)$ \\
\hline Drugi članovi obitelji & $7(4,8)$ & $4(2,6)$ \\
\hline Netko drugi & $2(1,4)$ & 0 \\
\hline
\end{tabular}

Što se tiče stava prema dojenju, dojilje su značajno učestalije imale stav da će uspjeti dojiti u odnosu na nedojilje (hi kvadrat test $=10,110 ; \mathrm{df}=2 ; \mathrm{p}=0,006$ ). Istraživane skupine nisu se značajno razlikovale $\mathrm{u}$ učestalosti pohađanja tečaja pripreme za porođaj (hi kvadrat test $=0,842 ; \mathrm{df}=1 ; \mathrm{p}=0,359)$ (Tablica 4$)$.

Tablica 4. Usporedba stava o dojenju i pohadanju tečaja za porođaj između skupina

\begin{tabular}{|c|l|l|l|l|l|}
\hline \multirow{2}{*}{ Varijable } & \multicolumn{2}{|l|}{ N \% ispitanica po skupini } & Hi kvadrat & \multirow{2}{*}{ test } & \\
\cline { 2 - 4 } & Dojilje & Nedojilje & p & \\
\hline Stav 0 dojenju & & & 10,110 & 0,006 \\
\hline Mislila sam da ću uspjeti dojiti & $86(59,3)$ & $78(50,3)$ & & \\
\hline Mislila sam da né́u uspjeti dojiti & $10(6,9)$ & $30(19,4)$ & & \\
\hline Nisam o tome razmišljala & $49(33,8)$ & $47(30,3)$ & & \\
\hline Tečaj pripreme za porođaj & & & 0,842 & 0,359 \\
\hline Da & $18(12,4)$ & $25(16,1)$ & & \\
\hline Ne & $127(87,6)$ & $130(83,9)$ & & \\
\hline
\end{tabular}

\section{Neke osobitosti u skupini dojilja}

U ispitanica koje su dojile djecu prosječna dob dojenčadi bila je 6 mjeseci života. Najmlađem dojenčetu bilo je 1 mjesec, a najstarijem 12 mjeseci života. $\mathrm{U}$ ispitivanom uzorku najučestalije je bilo zastupljeno isključivo dojenje (hi kvadrat test $=8,448 ; \mathrm{df}=1$; $\mathrm{p}=0,004)$. Za najučestaliji izvor podrške $u$ dojenju ispitanice dojilje navode da su bile same sebi podrška, a potom su tu podršku našle $u$ ocu djeteta ili majci (hi kvadrat test $=300,000 ; \mathrm{df}=7 ; \mathrm{p}<0,001$ ) (Slika 1). 


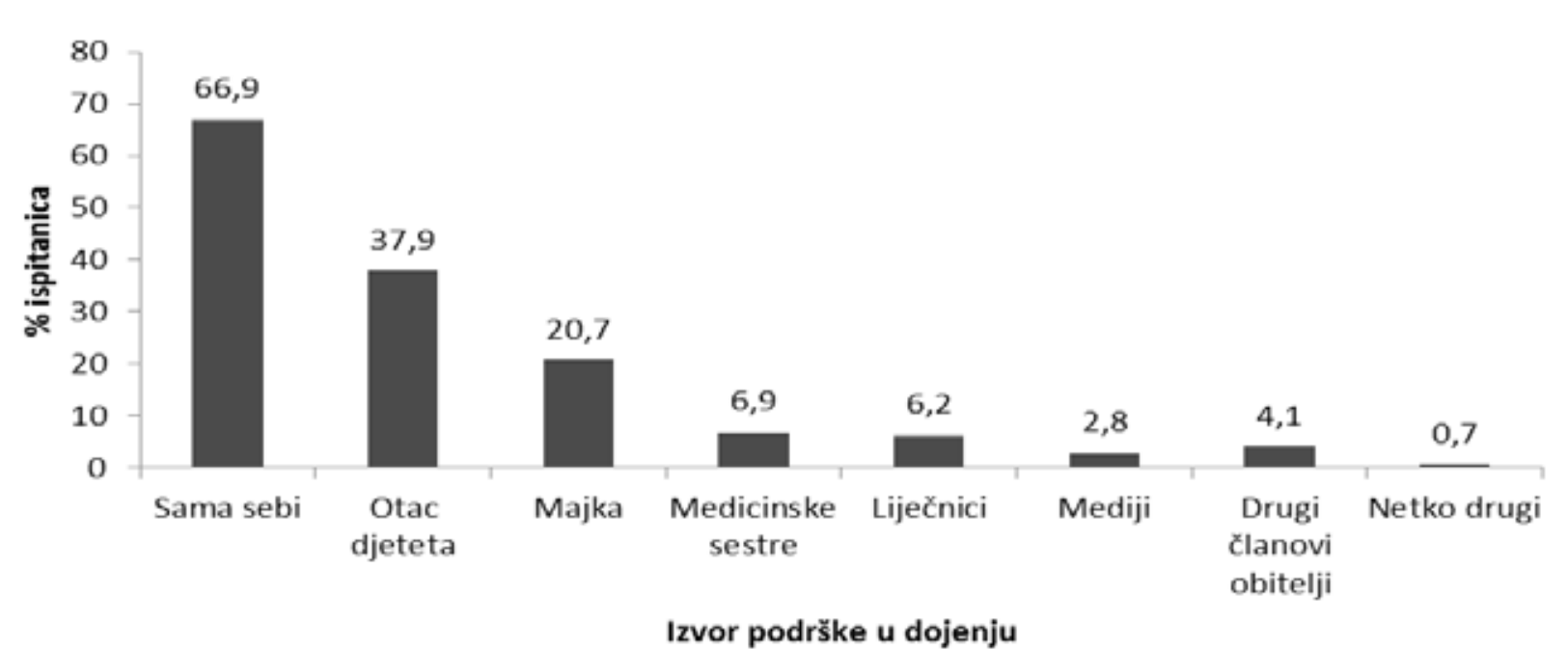

Slika 1. Izvor podrške u dojenju

\section{Neke osobitosti u skupini nedojilja}

U ispitanica koje nisu dojile djecu također prosječna dob dojenčadi bila je 6 mjeseci života. Najmlađem dojenčetu bilo je 1 mjesec, a najstarijem 12 mjeseci života.

Najučestalije naveden razlog prestanka dojenja bila je nedovoljna količina majčinog mlijeka, a potom umor i stres (hi kvadrat test $=414,964 ; \mathrm{df}=16 ; \mathrm{p}<0,001)$ (Slika 2).

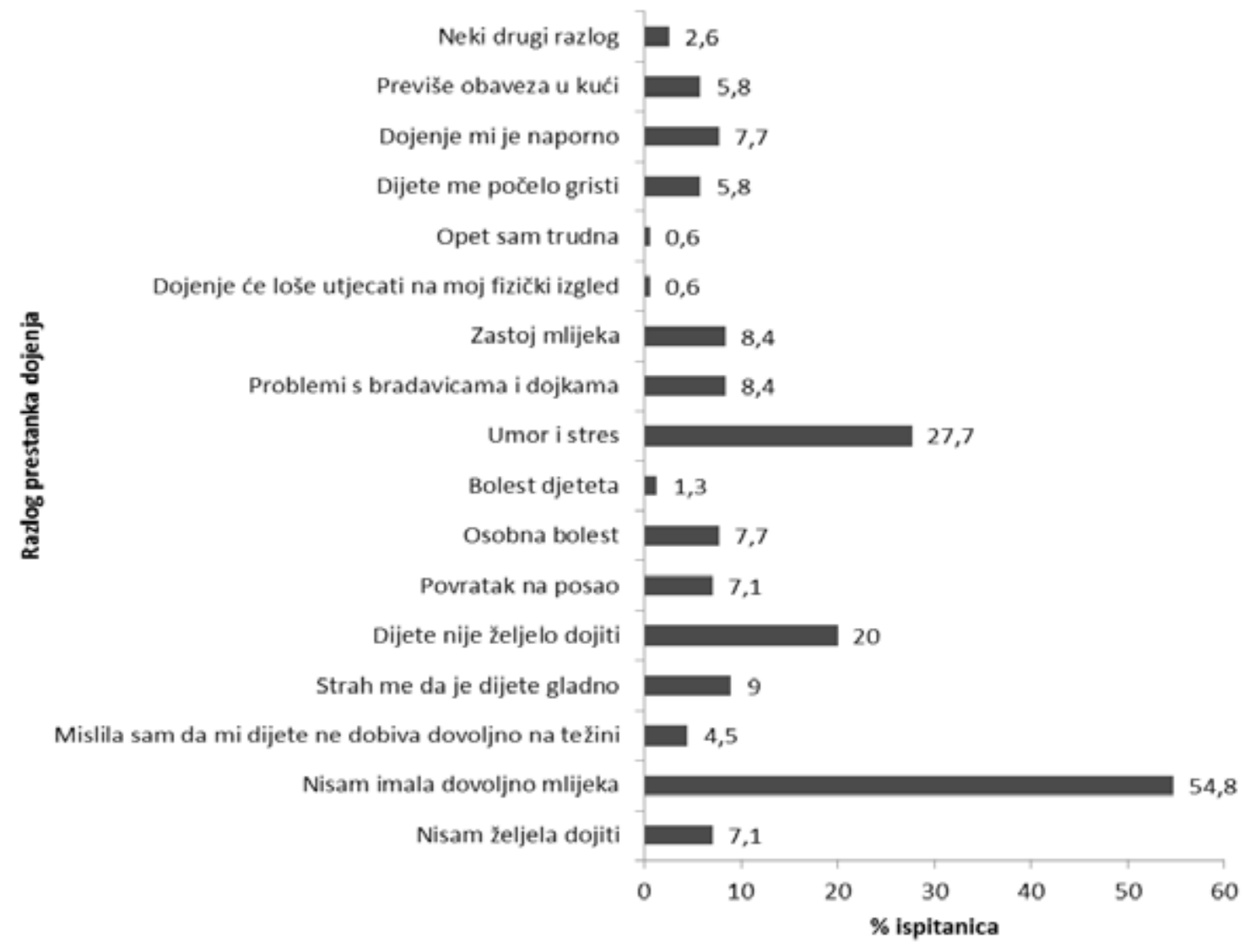

Slika 2. Razlozi prestanka dojenja 
$\mathrm{Na}$ odluku o prestanku dojenja ispitanice su najučestalije odgovorile da nije nitko utjecao, a od osoba koje su ipak utjecali, izdvojili su liječnike ( $\mathrm{n}=9 ;(5,8 \%)$ hi kvadrat test=632,750; $\mathrm{df}=6 ; \mathrm{p}<0,001)$ (Slika 3$)$.

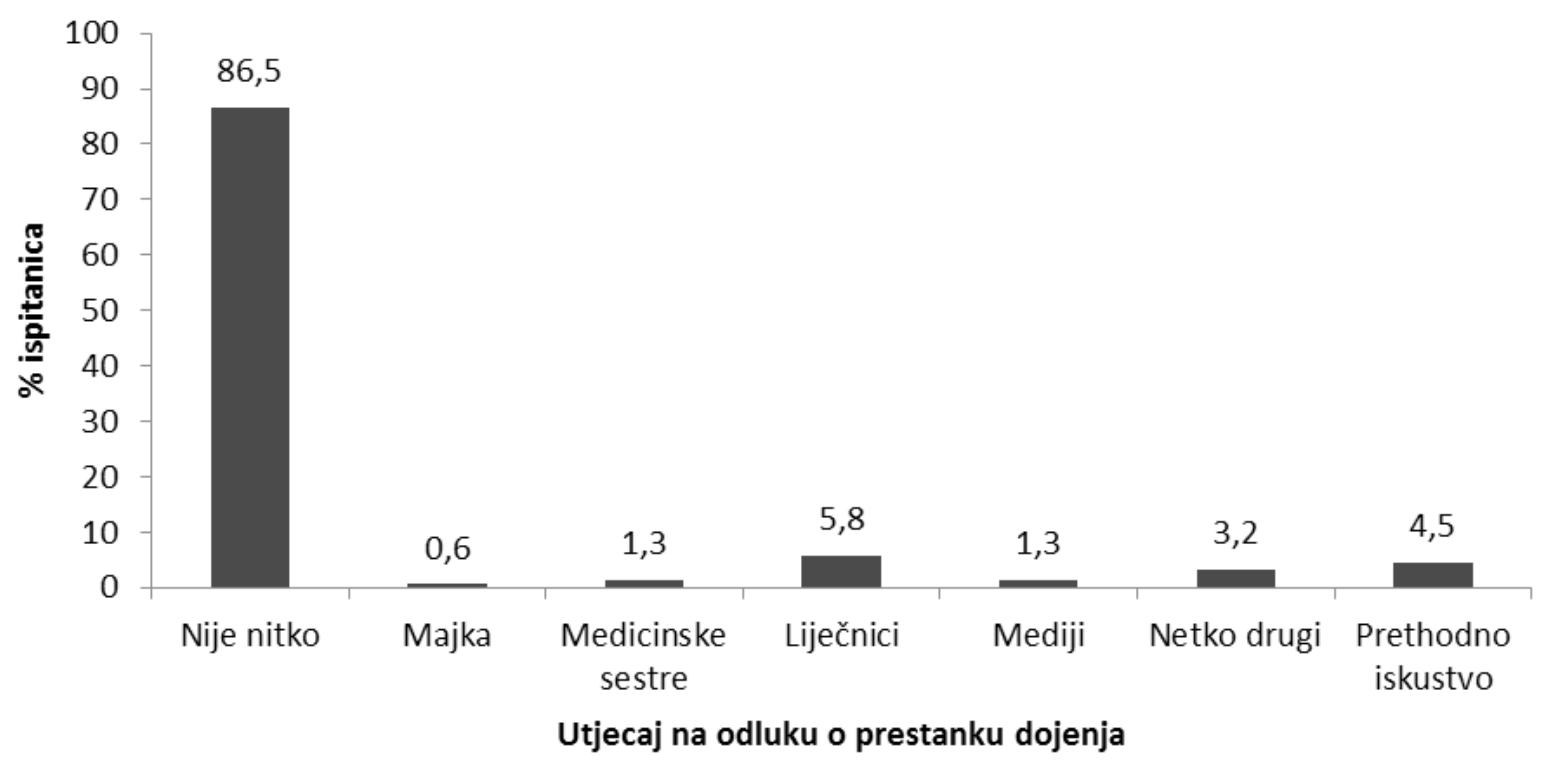

Slika 3. Utjecaj na odluku o prestanku dojenja

Ispitanice su se u većini slučajeva izjasnile da im je žao što ne doje dijete (n=102; $(65,8 \%)$ hi kvadrat test $=145,361 ; \mathrm{df}=3 ; \mathrm{p}<0,001)$ (Slika 4$)$.

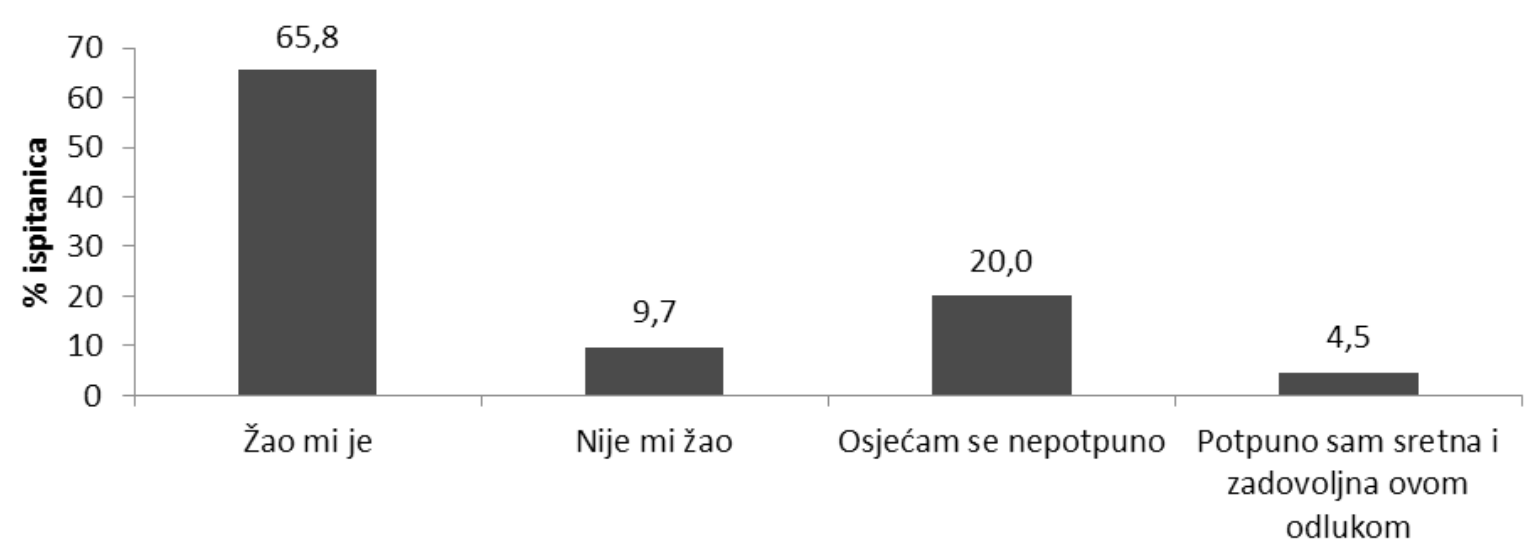

Unutrašnji doživljaj nedojenja djeteta

Slika 4. Unutrašnji doživljaj nedojenja djeteta

\section{RASPRAVA}

U ovom istraživanju najučestalije je bila zastupljena dobna struktura od 25-35 godina starosti, te nije postojala značajna razlika u dobnoj strukturi između ispitanica koje su dojile i onih koje nisu dojile iako neka istraživanja pokazuju da češće i dulje doje majke starije životne dobi (17). Što se tiče obrazovanja, 53 \% od ukupnog broja ispitanica je imalo srednju stručnu spremu (SSS), no uspoređujući dojenje i obrazovanje značajno više dojilja ima visoku stručnu spremu (VSS) u odnosu na nedojilje. Pretpostavio se značajan utjecaj obrazovanja na dojenje. Bolje obrazovanje podrazumijeva bolju informiranost i potpunije znanje o prednostima dojenja $(18,19)$. Međutim ima autora iz naše bliže sredine koji izvještavaju da majke sa srednjom i nižom stručnom spremom više i duže doje svoju djecu (20). U ispitivanom uzorku materijalni status je većinom ocijenjen kao dobar (70 
\% svih ispitanica), no uspoređujući dojilje i nedojilje, dobrim je ocijenjen u značajno većem broju u dojilja nego u nedojilja. Uspoređujući sa svjetskim istraživanjima odgovara činjenica da lošiji materijalni status utječe i na niži stupanj obrazovanja, samim time i na slabije saznavanje o prednostima dojenja $(21,22)$. Dobivenim rezultatima ove studije i drugih sličnih studija u svijetu i našoj sredini zaključak je na usmjeravanje edukacije na mlađe majke, slabije educirane i lošijeg materijalnog statusa $(23,24)$.

Promatrajući odnos zaposlenosti i dojenja, pretpostavilo se da će nezaposlene žene dojiti više, iz više razloga. Te žene ne veže obveza brzog povratka na radno mjesto. Nezaposlenim ženama nije zanemariv ni ekonomski razlog prakse dojenja. Međutim, razlika u prakticiranju dojenja između zaposlenih i nezaposlenih žena nije statistički značajan. Sličan rezultat je dobiven i u jednom istraživanju u Hrvatskoj (25). Mjesto stanovanja u ovoj analizi nije značajno utjecalo na praksu dojenja (26-28).

Ispitujući naviku pušenja, od ukupnog broja ispitanica $31,3 \%$ ispitanica puši, no nedojilje značajno više puše u odnosu na dojilje što je potvrđeno i drugim sličnim analizama $(27,28)$. Pušenje se povezuje $s$ ranijim prekidom dojenja, smanjenom proizvodnjom mlijeka i zaustavljanjem refleksa otpuštanja mlijeka. Dokazana je povezanost između pušenja i smanjene količine mlijeka, osobito u kombinaciji s depresijom. Pušenje smanjuje razinu prolaktina u krvi i na taj način smanjuje i proizvodnju mlijeka (29-31).

Rezultati su pokazali da se redoslijed djeteta ne razliku značajno kod majki koji doje i ne doje. Međutim majke koje su imale prethodno iskustvo dojenja u značajnoj mjeri su dojilje s čim se zaključuje da se jednom naučena i ustaljena praksa dojenja dalje lakše nastavlja. Ovim rezultatom potvrđuje se i hipoteza ovog rada, „a sličnih rezultata se može naći i u drugim sredinama" $(32,33)$. Rezultati su prokazali da je $70 \%$ ispitanica bilo dojeno, no uspoređeno prema skupinama dojilje su u značajno većem broju bile dojene kao djeca u odnosu na nedojilje $(33,34)$. Dojilje su značajno učestalije kao vrstu porođajna imale prirodan porođaj. Upravo zbog navedenog trebalo bi majkama koje su rodile carskim rezom posvetiti veću pažnju, što navode $\mathrm{i}$ istraživanja $u$ svijetu (35). Bolnice prijatelj djece usmjerene su na zaštitu, potporu i promociju dojenja i ujedno im je cilj smanjiti i stopu carskog reza koji značajno utječe na dojenje $(33,34)$.

Najviše informacija o dojenju dolazi iz primarne obitelji tj. od majčine majke. Drugo mjesto zauzimaju liječnici, pa zatim medicinske sestre i mediji. Uspoređujući dojilje i nedojilje primijetilo se da kod nedojilja mnogo učestalije nije bilo izvora informacija o dojenju (33). Otac djeteta je iznenađujuće nisko na toj ljestvici, što ukazuje na veliku potrebu intervencija zdravstvenih djelatnika na potrebu uključivanja oca u dojenje. Naime, dokazano je da žene čiji muževi ne podupiru dojenje raniju prestaju dojiti ili uopće ne doje (36-37).

U majki uključenih u ovo istraživanje bio je najzastupljeniji stav da će uspjeti dojiti no jedna značajno velika skupina o tome nije uopće razmišljala što ukazuje na činjenicu da majke nisu dovoljno pripremljene ni educirane o dojenju. Može se smatrati da majke koje doje svoju djecu već prethodno imaju jedan pozitivno izgrađen stav i da su to zapravo i samouvjerene žene. Velika većina žena donosi odluku o dojenju prije dolaska u rodilište, što potvrđuje i prethodno provedeno istraživanje do dvojenju u Mostaru (33). Boravak u rodilištu je vrlo kratak i praćen je brojnim i dramatičnim zbivanjima, a sve to iscrpljuje. Zato je najbolje da majka u rodilište dođe educirana u pogledu dojenja. Razni autori naglašavaju da edukaciju o dojenju treba započeti što ranije kao i to da pozitivan stav o dojenju utječe na kasniji bolji ishod dojenja $(38,39)$. Tečajem pripreme za porod u Mostaru budućim roditeljima se nastoji pružiti dovoljno informacija o trudnoći, razvoju ploda, prehrani, porođaju i boravku u rodilištu, a poseban naglasak u radu tečaja stavlja se na dojenje i njegu novorođenčeta. Inače, u rodilištu Sveučilišne kliničke bolnice Mostar moguća je i nazočnost očeva pri porodu, ali je potrebno da imaju potvrdu o završenom tečaju pripreme za porođaj. U ovom istraživanju većina ispitanica nije prošla tečaj pripreme za porod, samo $15 \%$ ispitanica ga je prošlo. Nizak postotak polaznica za trudnice je vjerojatni razlog zašto ovaj 
čimbenik nije značajnije utjecao na kasniju praksu dojenja. Jasno je da su naše ispitanice u ovom istraživanju zapravo nepripremljene za porod, samim time i za dojenje, a iskustva su pokazala da edukacija, tečajevi ili još bolje grupe za potporu dojenja zapravo jako dobro utječu na dojenje (40-42).

Kod ispitanica koje doje svoju djecu ispitali smo najučestaliji izvor podrške u dojenju, njih 67 \% smatra da su najveća podrška same sebi, što ukazuje na to da velika većina njih zapravo nema podršku. Izdvojili bih podršku supruga $38 \%$ i podršku vlastite majke $21 \%$, te jako mali postotak dojila koji pronalazi podršku u liječnicima i medicinskim sestrama. Zašto je to tako u našoj sredini? Mogući razlozi za to su nepostojanjem kontinuirane edukacije zdravstvenih radnika i nedostatak sustavnog nadzora nad rezultatima prakse dojenja ne samo u našoj sredini već i u cijeloj državi Bosni i Hercegovini (43). Također se taj nedostatak podrške osjeća u činjenici što u nas još uvijek nema grupa za potporu dojenja. Druga istraživanja pokazala su da je učestalost dojenja majki u grupama vrlo visoka $(40,41)$.

$\mathrm{U}$ ispitivanom uzorku majki dojilja najučestalije je bilo zastupljeno isključivo dojenje, čak 62 $\%$. To bi mogao biti prvi pozitivni pokazatelj još nedovoljno snažne akcije edukacije majki dojilja od strane pedijatara. Neke studije pokazuju da konačni ishod u svezi s dojenjem ovisi o intenzitetu intervencije pa tako majke s većim brojem kućnih posjeta savjetnice za dojenje, potom majke koje su prošle tečajeve pripreme za porod i educiranije majke doje dulje i imaju veću učestalost isključivog dojenja $(45,46)$.

Ispitujući skupinu majki nedojilja, najučestalije naveden razlog prestanka dojenja tj. nedojenja bila je nedovoljna količina majčinog mlijeka (55\%), a potom umor i stres $(28 \%)$. U literaturi se kao najčešći razlog prekida dojenja navodi nedovoljna proizvodnja mlijeka kako u svijetu tako i kod nas $(46,47)$. No nije li taj razlog često samo isprika za prestanak dojenja? Primarna agalaktija je vrlo rijetka, i moguće objašnjenje za to je da majke nisu dovoljno upoznate sa fiziologijom dojenja. Koliko žena uistinu ne može dojiti uopće se ne zna jer je ovo izuzetno rijetka pojava. Zdrava žena koja je rodila zdravo dijete sigurno može dojiti. Drugo objašnjenje može biti da majke nisu sigurne o potrebama svoje djece te pogrešno pretpostave da njihovog mlijeka nema dovoljno, nesigurne su i zasigurno nemaju odgovarajuću podršku. Očito je da majke trebaju biti više informirane o prednostima i tehnici dojenja. U prvim mjesecima života dojenje najčešće prestaje zbog straha majki, njihovog nedovoljnog samopouzdanja i slabe podrške. Dobra priprema prije poroda i dobra podrška nakon poroda povećavaju prevalenciju dojenja u svim sredinama (38-40).

Umor i stres kao razlog prestanka dojenja zapažen je i od strane drugih autora, a to također možemo objasniti kao odraz slabe podrške majci. Kod majki koje prvi put rađaju, osjećaj tjeskobe i osjećaj zabrinutosti je neizbježan nakon porođaja. Sve majke u to vrijeme trebaju potporu i utjehu svog supruga, obitelji, prijatelja i zdravstvenih djelatnika $(48,49)$.

$\mathrm{Na}$ odluku o prestanku dojenja ispitanice su najučestalije odgovorile da nije nitko utjecao, što znači da majke zapravo i nisu donosile odluku a poslije shvate da se nešto dogodilo. I naravno, u većini slučajeva majke su izjasnile da im je žao što ne doje dijete te da se osjećaju nepotpuno. Ovaj rezultat nam daje uvid u unutarnji osjećaj majke. Iskrene su prema sebi, znaju da je dojenje nešto što je priroda napravila savršenim, a one taj dio sebe nisu ostvarile. Možda bi se detaljnije trebalo proučiti raspoloženje majki nedojilja, majki koje nemaju pozitivan stav o dojenju već i prije samog poroda. Možda bi se tu našlo dosta depresivnih majki sudeći po usporedbi stava uspjeha dojenja prije početka dojenja i značajnoj razlici, gdje čak $50 \%$ nedojilja ili misli da neće uspjeti dojiti ili o tome ne razmišlja. Možda bi se tada još bolje razumjeli čimbenici nedojenja? Istraživanja su potvrdila da žene s postporođajnom depresijom manje i doje, a ista ta istraživanja naglašavaju pravovremenu terapiju kao i pružanje veće potpore dojenja takvim majkama (46). Zdravstveni djelatnici (liječnik obiteljske medicine, ginekolog, pedijatar, babica i medicinska sestra) moraju postati svjesni dijela odgovornosti za edukaciju roditelja i djece (50). 


\section{ZAKLJUČAK}

Rezultati ovog istraživanja pokazali su: da manje obrazovane majke, majke lošijeg materijalnog statusa, pušačice, majke koje nemaju prethodno stečeno iskustvo dojenja, kao i majke koje su rađale carskim rezom većinom manje doje svoju djecu. Nedojilje kao glavni razlog prestanka dojenja navode nedostatak mlijeka, a potom umor i stres. To ukazuje na potrebu edukacije o dojenju, jer dobra priprema i edukacija prije poroda i dobra podrška nakon poroda uvelike bi pridonijela povećanju prevalencije dojenja.

\section{LITERATURA}

1. Kajgana M. Povijest dojenja. Portal djeca. [Internet] Dostupno na: http://www.djeca.org/index. $\mathrm{php} /$ sve-o-djeci/teme/dojenje1/319-povijest-dojenja [Pristupljeno: 07.02.2013.]

2. Goldman AS. Breastfeeding lessons from the past century. Pediatr Clin North Am. 2001;48:23-25.

3. Ilić T. Prvi korak u život. Pouke o njezi dojenčeta. Život i zdravlje. Centralni higijenski zavod. Sarajevo; 1958;33.

4. Spock B. Što treba znati o odgoju djeteta. Novinarsko izdavačko poduzeće. Zagreb; 1961;31-45.

5. Meves C. Sudbina djece u našim rukama. Iskustva iz psihagoške prakse. Četvrto hrvatsko izdanje. Karitativni fond UPT. Đakovo; 2000;13-20.

6. Mesihović - Dinarević S. i sur., Pedijatrija za studente visoke zdravstvene škole. Sa Vart. Sarajevo; 2005;36-44.

7. Mardešić D. i sur., Pedijatrija. Sedmo, dopunjeno izdanje. Školska knjiga. Zagreb; 2003;240-61.

8. Narodni zdravstveni list. Svjetski tjedan dojenja 25 godina zaštite dojenja. Mjesečnik za uređenje zdravstvene kulture. Welt d.o.o. Rijeka; 2006;3-4.

9. United nations general assembly. Convetion on the rights of the child. New York. 1989. [Internet] Dostupno na: http://www.unicef.org/crc/ [Pristupljeno 07.05.2012.]

10. UNICEF/WHO. Innocenti Declaration 2005 On infant and young child feeding. Florence. Italy. [Internet] Dostupno na: http://www. unicef.org/nutrition/files/innocenti2005m_FINAL_ARTWORK_3_MAR.pdf [Pristupljeno 07.05.2012.]
11.WHO/UNICEF. Global strategy for infant and young child feeding. 2003. Geneva. [Internet] Dostupno na: http://www.unicef.org/nutrition/ files/Global_Strategy_Infant_and_Young_Child_Feeding.pdf [Pristupljeno 07.05.2012.]

12. Ademović M, Purivata-Dračić S. Studija o prirodnoj ishrani dojenčadi u $\mathrm{FBiH}$. Udruženje za unapređenje dojenja. Sarajevo; 1998;1-74

13. Šumanović-Glamuzina D. Breastfeeding practice in Bosnia and Herzegovina. J Pediatr Neonat Individual Med. 2013;2:55-62.

14.Pillitteri A. Maternal and child health nursing (Care of the childbearing and childrearing family). Second edition. J.B. Lippincott Company. Philadelphia. 1995;685-700.

15. Vojvodić-Schuster S. Vježbe za trudnice; cjeloviti program vježbanja kroz tromjesečja i priprema za porođaj. Biovega. Zagreb; 2004;145-50.

16. Projekat: Dojenje u Federaciji Bosni i Hercegovini. Završni izvještaj. Zavod za javno zdravstvo FBiH. Sarajevo; 1999;2-21.

17. Dubois L, Girard M. Social inequalities in infant feeding during the first year of life. The Longitudinal Study of Child Development in Québec (LSCDQ 1998-2002). Public Health Nutr. 2003;6:773-83.

18. Riva E, Banderali G, Agostoni C, Silano M, Radaelli G, Giovannini M. Factors associated with initiation and duration of breastfeeding in Italy. Acta Paediatr. 1999;88:411-5.

19. Rossem L. et al. Breastfeeding patterns among ethnic minorities: the Generation R Study J. Epidemiol. Community Health 2010;64:1080-85.

20. Obradović K. Trajanje dojenja u gradu Solinu od 1988. do 1998. godine. Pediatr Croat. 2000;44: 157-60.

21. Alan S. Ryan, PhD. The Resurgence of Breastfeeding in the United States. Pediatrics. 1997;99: 101-21.

22. Berović N. Impact of sociodemographic features of mothers on breastfeeding in Croatia: questionnaire study. Croat Med J. 2003;44:596-600.

23. Šimić T, Šumanović-Glamuzina D, Boranić M, Vuksić I, Boban A. Breastfeeding practices in 
Mostar, Bosnia and Herzegovina: cross-sectional self-report study. Croat Med J. 2004;45: 38-43.

24. Alan S. Ryan et al. Breastfeeding Continues to Increase Into the New Millennium. Pediatrics. 2002;110: 1103-09.

25. Čatipović M, Čatipović V, Novalić D, Bogeljić J, Fehir-Radanović I. Važni čimbenici u odluci o dojenju. Paediatria Croatica. Vol. 46. No. 3. 2002 :107-14.

26.Liu J, Shi Z, Spatz D, Loh R, Sun G, Grisso J. Social and demographic determinants for breastfeeding in a rural, suburban and city area of South East China. Contemp Nurse. 2013.

27. Perez-Escamilla R. Breastfeeding in Africa and the Latin American and Caribbean region: the potential role of urbanization. J Trop Pediatr. 1994;40:137-43.

28. Salih MA, el Bushra HM, Satti SA, Ahmed M elF, Kamil IA. Attitudes and practices of breast-feeding in Sudanese urban and rural communities. Trop Geogr Med. 1993;45: 171-4.

29. Mullen PD, Richardson MA, Quinn VP, Ershoff DH. Postpartum return to smoking: who is at risk and when. Am J Health Promot. 1997;11: 323-30.

30. Hopkinson JM, Schanler RJ, Fraley JK, Garza C. Milk production by mothers of premature infants: influence of cigarette smoking. Pediatrics. 1992;90: 934-8.

31. Northrup TF, Wootton SH, Evans PW, Stotts AL. Breastfeeding practices in mothers of high-respiratory-risk NICU infants: impact of depressive symptoms and smoking. J Matern Fetal Neonatal Med. 2013.

32. Barriere H, Tanguy M, Connan L, Baron C, Fanello S. Prenatal breastfeeding information: survey in Pays de Loire, France. Arch Pediatr. 2011;18: 945-54.

33. Rossman B. Breastfeeding peer counselors in the United States: helping to build a culture and tradition of breastfeeding. J Midwifery Womens Health. 2007;52:631-7.

34. Primo CC, Caetano LC. The decision to breastfeed: grandmother's view. J Pediatr (Rio J). 1999;75: 449-55.
35. Di Mario S, Cattaneo A, Gagliotti C, Voci C, Basevi V. Baby-Friendly Hospitals and Cesarean Section Rate: A Survey of Italian Hospitals. Breastfeed Med. 2013.

36. Mannion CA, Hobbs AJ, McDonald SW, Tough SC. Maternal perceptions of partner support during breastfeeding. Int Breastfeed J. 2013.

37. Mitchell-Box KM, Braun KL. Impact of Male-Partner-Focused Interventions on Breastfeeding Initiation, Exclusivity, and Continuation. J Hum Lact. 2013.

38. Bolam A, Manandhar DS, Shrestha P, Ellis M, Costello AM. The effects of postnatal health education for mothers on infant care and family planning practices in Nepal: a randomised controlled trial. BMJ. 1998;316: 805-11.

39. Bosnjak AP, Grguric J, Stanojevic M, Sonicki Z. Influence of sociodemographic and psychosocial characteristics on breastfeeding duration of mothers attending breastfeeding support groups. J Perinat Med. 2009;37:185-92.

40.Zakarija-Grkovic I. i sur. Hospital practices and breastfeeding rates before and after the UNICEF/ WHO 20-hour course for maternity staff. J Hum Lact. 2012;28:389-99.

41. Cwiek $\mathrm{D}$. The impact of education in birthing schools on the course of pregnancy, labor, puerperium, and neonatal care. Ann Acad Med Stetin. 2006;52:79-90.

42. Hörnell A, Aarts C, Kylberg E, Hofvander Y, Gebre-Medhin M. Breastfeeding patterns in exclusively breastfed infants: a longitudinal prospective study in Uppsala, Sweden. Acta Paediatr. 1999;88:203-11.

43. Bosnia and Herzegovina. Info centar. Istraživanje višestrukih pokazatelja (MICS). BiH 2011. - 2012. [Internet] Dostupno na: http://www.unicef.org/bih/ba/06_IV_Ishrana.pdf [Pristupljeno 07.05.2013.]

44. Oche MO, Umar AS, Ahmed H. Knowledge and practice of exclusive breastfeeding in Kware, Nigeria. Afr Health Sci. 2011;11:518-23.

45. Ogbonna C, Daboer JC. Current knowledge and practice of exclusive breastfeeding among mothers in Jos, Nigeria. Niger J Med. 2007;16:256-60. 

području Mostara. Zdravstveni glasnik. 2016;2: 35-46.

46. Shani M, Shinwell E. Breastfeeding characteristics and reasons to stop breastfeeding. Harefuah. 2003;142:426-8.

47. Dozier AM, Nelson A, Brownell E. The Relationship between Life Stress and Breastfeeding Outcomes among Low-Income Mothers. Adv Prev Med. 2012.

48. Li J, Kendall GE, Henderson S, Downie J, Landsborough L, Oddy WH. Maternal psychosocial well-being in pregnancy and breastfeeding duration. Acta Paediatr. 2008;97:221-5.
49.Dennis CL, McQueen K. The relationship between infant-feeding outcomes and postpartum depression: a qualitative systematic review. Pediatrics. 2009;123:736-51.

50. Ademović M. Savremeni stavovi ishrane dojenčadi. Inicijativni odbor za unapređenje dojenja. UNICEF-Ured za Bosnu i Hercegovinu. Sarajevo. $2000 ; 7-48$. 


\title{
PREVALENCE OF BREASTFEEDING AND FACTORS THAT DETERMINE WITHDRAWAL OF BREASTFEEDING IN THE AREA OF MOSTAR
}

\author{
Ivana Palac ${ }^{1,3}$, Darinka Šumanović-Glamuzina ${ }^{2,3}$, Iva Mikulić ${ }^{1,2,3}, G$ Gordan Galić ${ }^{1,3}$ \\ ${ }^{1}$ Department of Surgery; University Clinical Hospital Mostar \\ ${ }^{2}$ Department of Pediatrics, University Clinical Hospital Mostar \\ ${ }^{3}$ Faculty of Health Studies, University of Mostar
}

\begin{abstract}
INTRODUCTION: Breastfeeding is natural and best diet in infancy. Modernization of human society, in addition to many advantages, has also some disadvantages, especially getting away from nature and some natural processes, one of which is breastfeeding. Recent scientific studies and extensive epidemiological studies have demonstrated the benefits of a natural diet on the health of children. Breastfeeding benefits the child, mother, family and society as a whole, therefore, the protection, promotion and support of breastfeeding in public are health priority for all countries.

OBJECTIVE: To compare and determine the socio-demographic and other specific characteristics between nursing mothers and non-nursing mothers.
\end{abstract}

RESPONDENTS AND METHODS: The study was conducted in the medical center in Mostar, at the Department of Health Care of Infants and Young Children in January 2013. Questionnaire with previously signed informed consent, examined a total of 300 randomly selected but purposely divided into two roughly equal groups of nursing (145) and non-nursing mothers (155).

RESULTS: Comparisons between groups of nursing mothers and non-nursing mothers confirmed a statistically significant difference in relation to education, financial status, the impact of smoking, previous lactation, type of delivery and the impact of breast-feeding mother as a child. The influence of attitude about the success of breastfeeding before the start of breastfeeding has shown as an important. Mothers who are nursing their children say that they were their own, the most common source of support to breastfeeding and then the support was also found in the child's father or mother. The most frequently stated reason for weaning was insufficient quantity of breast milk, followed by fatigue and stress.

CONCLUSION: The results indicate the need for education about breastfeeding, because good preparation and training before delivery and good support after delivery would greatly contribute to the increase in the prevalence of breastfeeding.

Key words: breastfeeding, risk factors, baby.

Correspondence:

M.Sc. Ivana Palac, a registered nurse.

e-mail: ivanapalac1985@gmail.com 